\title{
Proses Pengambilan Keputusan Efektif Islami di Sekolah (Studi Kasus di MTs al-Imam Cikembar Kab. Sukabumi)
}

\author{
Farida Nur Rahma ${ }^{1}$, Mada Wijaya Kusumah ${ }^{1 *}$ \\ 1Program Studi Bahasa Arab, Sekolah Tinggi Ilmu Bahasa Arab Ar Raayah, Sukabumi, Indonesia
}

ARTICLE INFO

Keywords

Pendidikan Islam, Decision-

making, Islam, Leadership

\section{*Corespondence \\ madawk@arraayah.ac.id}

\section{Article History}

Received 12 November 2018

Accepted 28 Maret 2019

Published online 10 Agustus 2019

\section{ABSTRACT}

Tujuan penelitian ini yaitu menemukan prinsip-prinsip dalam proses pengambilan keputusan yang efektif dan Islami. Penelitian ini menggunakan metode studi lapangan (field research) dan studi pustaka (library research). Dari kajian lapangan di MTs AlImam peneliti menemukan masalah dalam proses pengambilan keputusan berupa tidak ada pembagian kewenangan yang jelas sehingga terjadi dualisme kepemimpinan. Ada beberapa hal yang harus diperhatikan struktural MTs Al-Imam yaitu: (1) Pembagian kewenangan yang jelas, (2) Pengelolaan akademik sekolah/madrasah itu percayakan pada ahli/praktisi, (3) Menjadikan hukum Islam sebagai pedoman pengambilan keputusan agar tidak terjadi kejanggalan kebijakan (4) Menggali informasi akademik dari praktisi, (5) Menjalankan musyawarah mufakat.

The purpose of the research is to discover principles in the decision-making process is effective and Islami. This research using the method of the study field (field research) and studies library (library research). Whereas through fieldwork in MTs Al-Imam researchers found the problem in the decision-making process of which there is no clear division of authority so dualism leadership. So there are some things to watch out for structural MTs Al-Imam, namely: (1) there is a clear division of authority, (2) in the management of madrasah school/academic trust in experts/practitioners, (3) make Islamic law as the guideline retrieval the decision to keep policy gaffe occurred (4) academic information Dug from practitioners, (5) Discussion consensus.

\section{PENDAHULUAN}

Pembukaan Undang-Undang Dasar Negara Republik Indonesia 1945 mengamanahkan bahwa pemerintah negara Indonesia harus mencerdaskan kehidupan bangsa dalam bentuk pemberian hak pendidikan kepada setiap warga dan pemerintah wajib membiayainya. Adapun pengusahaan dan penyelenggaraannya diatur lebih lanjut dalam Undang-Undang Sistem Pendidikan Nasional no. 20 tahun 2003.

Sistem pendidikan nasional yang diselenggarakan pemerintah harus dilakukan secara merata dan berkualitas. Merata dari aspek kesempatan pendidikan. Berkualitas dari aspek efisiensi pengelolaan pendidikannya. Bahkan harus memiliki relevansi dengan tuntutan perubahan kehidupan lokal, nasional dan global. Sehingga harus selalu ada pembaharuan pendidikan secara terencana, terarah dan berkesinambungan.

Pendidikan yang berkualitas harus didukung dengan pengelolaan atau manajemen yang berkualitas. Sehingga, pemerintah Indonesia menetapkan standar pendidikan nasional. Standar tersebut meliputi Standar Isi, Standar Kompetensi Lulusan, Standar Proses, Standar Tenaga Pendidik dan Tenaga Kependidikan, Standar Sarana dan Prasarana, Standar Pengelolaan, Standar Pembiayaan, dan Standar Penilaian Pendidikan.

Standar pendidikan nasional tersebut adalah kriteria minimal, sehingga pihak penyelenggara pendidikan di pusat maupun daerah harus berusaha untuk memenuhinya. Terutama peran pihak pengelola sekolah yaitu kepala sekolah/ madrasah sangat menentukan. Karena kepala sekolah/madrasah inilah yang bertanggungjawab, memutuskan atau menetapkan kebijakan yang berkaitan usaha sekolah untuk memenuhi standar pendidikan nasional (Kodrat, 2019; Bin Tata Rosita, Syahidin, \& Rizal, 2019).

Begitu pentingnya pengelolaan pendidikan terutama untuk satuan pendidikan dasar dan menengah maka pemerintah menetapkan standar pengelolaan pendidikan dasar dan menengah melalui Peraturan Menteri Pendidikan Nasional no. 19 tahun 2007 dan standar pengelolanya (kepala sekolah/madrasah) melalui Peraturan Menteri Pendidikan Nasional no.13 tahun 2007.

Peraturan Menteri Pendidikan Nasional no. 19 tahun 2007 mengamanahkan pengelola sekolah untuk mengelola dengan baik visi, misi, tujuan, kurikulum, kalender pendidikan/ akademik, struktur organisasi sekolah/ madrasah, pembagian tugas di antara 
guru, pembagian tugas di antara tenaga kependidikan, peraturan akademik, tata tertib sekolah/ madrasah, kode etik sekolah/ madrasah, biaya operasional sekolah/madrasah, evaluasi proses pembelajaran dan evaluasi program kerja tahunan.

Pengelolaan pendidikan akan berjalan dengan baik jika dikelola oleh orang atau kepala sekolah/madrasah yang berkualitas dan kompeten. Maka pemerintah melalui Peraturan Menteri Pendidikan Nasional no.13 tahun 2007 menetapkan bahwa seorang kepala sekolah/madrasah harus memenuhi standar kualifikasi umum dan khusus serta memenuhi beberapa kompetensi baik kompetensi kepribadian, manajerial, kewirausahaan, supervisi dan sosial.

Adapun tugas kepala sekolah/madrasah sesuai UU Sisdiknas no. 20 tahun 2003 adalah sebagai berikut:

a. menjabarkan visi ke dalam misi target mutu;

b. merumuskan tujuan dan target mutu yang akan dicapai;

c. menganalisis tantangan, peluang, kekuatan, dan kelemahan sekolah/ madrasah;

d. membuat rencana kerja strategis dan rencana kerja tahunan untuk pelaksanaan peningkatan mutu;

e. bertanggung jawab dalam membuat keputusan anggaran sekolah/ madrasah;

f. melibatkan guru, komite sekolah dalam pengambilan keputusan penting sekolah/ madrasah. Dalam hal sekolah/ madrasah swasta, pengambilan keputusan tersebut harus melibatkan penyelenggara sekolah/ madrasah;

g. berkomunikasi untuk menciptakan dukungan intensif dari orang tua peserta didik dan masyarakat;

h. menjaga dan meningkatkan motivasi kerja pendidik dan tenaga kependidikan dengan menggunakan sistem pemberian penghargaan atas prestasi dan sangsi atas pelanggaran peraturan dan kode etik;

i. menciptakan lingkungan pembelajaran yang efektif bagi peserta didik;

j. $\quad$ bertanggung jawab atas perencanaan partisipatif mengenai pelaksanaan kurikulum;

k. melaksanakan dan merumuskan program supervisi, serta memanfaatkan hasil supervisi untuk meningkatkan kinerja sekolah/madrasah;

l. meningkatkan mutu pendidikan;

m. memberi teladan dan menjaga nama baik lembaga, profesi, dan kedudukan sesuai dengan kepercayaan yang diberikan kepadanya;

n. memfasilitasi pengembangan, penyebarluasan, dan pelaksanaan visi pembelajaran yang dikomunikasikan dengan baik dan didukung oleh komunitas sekolah/madrasah;

o. membantu, membina, dan mempertahankan lingkungan sekolah/madrasah dan program pembelajaran yang kondusif bagi proses belajar peserta didik dan pertumbuhan profesional para guru dan tenaga kependidikan;

p. menjamin manajemen organisasi dan peng-operasian sumber daya sekolah/madrasah untuk menciptakan lingkungan belajar yang aman, sehat, efisien, dan efektif;

q. menjalin kerja sama dengan orang tua peserta didik dan masyarakat, dan komite sekolah/madrasah menanggapi kepentingan dan kebutuhan komunitas yang beragam, dan memobilisasi sumber daya masyarakat; memberi contoh/ teladan/ tindakan yang bertanggung jawab.

Salah satu peran kepala sekolah/madrasah yang sangat strategis adalah pengambilan keputusan penting sekolah/madrasah. Karena proses pengambilan keputusan ini hampir dilakukan setiap saat, melibatkan banyak pihak terutama guru dan komite sekolah dan dilakukan dalam semua bidang garapan sekolah. Keputusan yang diambil bisa jadi menyelesaikan masalah, bisa juga menambah masalah. Hal ini tergantung pada kepiawaian kepala sekolah/madrasah menjalani proses pengambilan keputusannya. Salusu (1996) berpendapat bahwa;

Ia merupakan kegiatan sentral dari manajemen, merupakan kunci kepemimpinan, atau inti kepemimpinan, sebagai suatu karakteristik yang fundamental, sebagai jantung kegiatan administratif, suatu saat kritis bagi tindakan administratif, pengambilan keputusan adalah kegiatan yang paling penting dari semua kegiatan karena di dalamnya manajer terlibat, dan itu merupakan pertanggungjawaban utama dari semua administrator melalui suatu proses tempat keputusankeputusan dibuat dan dilaksanakan.

Maka penting dilakukan penelitian tentang proses pengambilan keputusan efektif dan Islami. Karena banyak pemimpin mengambil keputusan tapi tidak solutif dan tidak berdampak positif dan cenderung pragmatis dalam arti hanya bersandar pada fakta tapi tidak bersandar pada nilai atau keyakinan atau ideologi tertentu, sehingga keputusan yang diambil sarat kepentingan. Maka sangat penting dikaji proses pengambilan keputusan efektif Islami di sekolah.

\section{METODE}

Metode penelitian jurnal ini adalah studi lapangan (field research) dan studi pustaka (library research). Data yang ditemukan kompeten dan dapat dipertanggungjawabkan karena peneliti langsung melakukan penelitian di MTs Al-Imam dengan mengambil data melalui wawancara dan kuisioner. Adapun wawancara dilakukan dengan pihak pimpinan yayasan dan kepala MTs Al-Imam. Isi wawancara terfokus pada mekanisme pengambilan keputusan dalam penentuan visi, misi, tujuan, kurikulum, kalender pendidikan/ akademik, struktur organisasi sekolah/madrasah, pembagian tugas di antara guru, pembagian tugas di antara tenaga kependidikan, peraturan akademik, tata tertib sekolah/madrasah, kode etik sekolah/madrasah, biaya operasional sekolah/madrasah, evaluasi proses pembelajaran dan evaluasi program kerja tahunan. Sedangkan kuisioner memilih responden yaitu sekretaris MTs dan salah satu staff pengajar MTs Al-Imam. Isi kuisioner adalah penilaian terhadap kompetensi kepala sekolah dalam lima dimensi kompetensi yaitu kepribadian, manajerial, kewirausahaan, supervisi, dan sosial. Pilihan jawaban hanya tiga alternatif yaitu B (bagus), S (sedang), dan K (kurang). B (bagus) bernilai 3, S (sedang) bernilai 2, dan K (kurang) bernilai 1. Kesimpulan penilaian kompetensi diambil dari mean atau rerata nilai.

Studi pustaka dalam penelitian ini mengacu pada tiga sumber utama yaitu: A) Sumber pustaka yang bertema proses pengambilan keputusan yaitu Al Quran; B) Peraturan Menteri Pendidikan Nasional RI no. 19 tahun 2007. Dari Peraturan Menteri Pendidikan Nasional ini dapat diketahui posisi peran kepala sekolah dalam menetapkan keputusan. Mulai dari memimpin rapat penetapan visi, misi dan tujuan sekolah, perumusan rencana kerja menengah dan tahunan, memutuskan struktur organisasi sekolah, pengelolaan bidang akademik, bertanggungjawab atas tersusunnya kurikulum, menetapkan kalender pendidikan/ akademik, bertanggungjawab terhadap kegiatan pembelajaran, peraturan akademik, pedoman pengelolaan biaya investasi dan operasional sekolah/madrasah, penciptaan suasana, iklim, dan lingkungan pendidikan, tata tertib sekolah/madrasah, kode etik sekolah/madrasah, evaluasi proses pembelajaran dan evaluasi program kerja tahunan; C) Peraturan Menteri Pendidikan Nasional RI no. 13 tahun 2007. Dari Peraturan Menteri Pendidikan Nasional ini dapat diketahui standar kepala sekolah/madrasah yang 
ditetapkan pemerintah. Seorang kepala sekolah/madrasah harus memenuhi kualifikasi (umum dan khusus) dan kompetensi (kepribadian, manajerial, kewirausahaan, supervisi, dan sosial)

Jika visi pendidikan nasional Indonesia tersebut dicermati lebih lanjut, maka kita memerlukan indikator yang rinci terkait apakah yang dimaksud dengan pranata sosial yang kuat dan berwibawa, manusia berkualitas, dan proaktif menjawab tantangan jaman yang berubah. Pembahasan pendidikan akan difokuskan pada pendidikan pada jenjang menengah. Oleh karena itu, kita dapat melihatnya secara umum untuk level pendidikan menengah dalam UU Nomor 23 Tahun 2006 tentang Standar Kompetensi Lulusan untuk Satuan Pendidikan Dasar dan Menengah.

\section{PEMBAHASAN}

\subsection{Makna Proses Pengambilan Keputusan Efektif Islami}

Dalam sebuah organisasi, keberadaan pemimpin sangatlah penting. Karena, pemimpin adalah pelopor yang akan mengelola organisasinya. Langkah atau aktifitas organisasi adalah hasil dari sebuah proses pengambilan keputusan oleh pemimpin atas peluang yang dimiliki dan tantangan yang dihadapi organisasi. Pemimpin harus mampu mempengaruhi orang lain dengan cara mengilhami, menyadarkan, membangkitkan dan mengajak. Abduh (2016) mengatakan bahwa organisasi hanya akan berfungsi jika para pemimpin memiliki kemampuan mengambil keputusan dan memerintahkan pelaksanaannya kepada anggota organisasi sesuai dengan bidang tugas dan tanggung jawabnya. Hal senada dikemukakan oleh Soebagio Atmodiwiro dan Soeranto Totosiswanto yang mengutip dari Redding dan Casey bahwa salah satu kemampuan pemimpin adalah pengambilan keputusan (Abdul Rahmat 2013).

Secara bahasa menurut Ety Rohaety dalam Abduh (2016) istilah "Pengambilan Keputusan” sesungguhnya adalah terjemahan dari bahasa Inggris decision maker, yang berasal dari kata decision dan maker keduanya berasal dari bahasa Inggris. Decision berarti keputusan dan maker adalah pembuat. Dalam bahasa Latin, kata decide berasal dari prefik de yang berarti off, dan kata caedo yang berarti to cut. Hal ini berarti proses kognitif cut off sebagai tindakan memilih di antara beberapa alternatif yang mungkin. Jadi proses pengambilan keputusan adalah langkah-langkah yang ditempuh seseorang untuk memilih tindakan tertentu yang memungkinkan untuk mengatasi masalah tertentu dan diharapkan memiliki pengaruh atau dampak positif.

Pengambilan keputusan harus memperhatikan efektifitas sehingga ada kesesuaian antara masalah yang dihadapi dengan penyelesaian masalah yang diambil. Efektivitas adalah merupakan kemampuan untuk memilih tujuan dengan memanfaatkan sarana dan prasarana yang tepat untuk mencapai tujuan (Putra, 2014). "efektif tidaknya suatu keputusan dapat dilihat dari penerimaan (acceptability) dan kemudian dibandingkan dengan kualitas (quality) keputusan itu sendiri. Menurutnya keputusan yang berkualitas itu adalah yang sesuai dengan keadaan intern sekolah yang meliputi: dana yang tersedia, kemampuan karyawan, kelengkapan dari peralatan, struktur organisasi, tersedianya informasi yang dibutuhkan pimpinan dan lain sebagainya (Putra, 2014). Sebagai pemimpin pendidikan di sekolah, kepala sekolah/madrasah memiliki tanggung jawab sepenuhnya untuk mengembangkan seluruh sumber daya sekolah. Efektivitas kepemimpinan kepala sekolah tergantung kepada kemampuan bekerja sama dengan seluruh warga sekolah, serta kemampuannya mengendalikan pengelolaan sekolah untuk menciptakan proses belajar mengajar.

Adapun penyematan "Islami" dalam "proses pengambilan keputusan efektif Islami" bermakna memberi sifat pada proses pengambilan keputusan. Bahwa proses pengambilan keputusan itu harus bersandar pada aqidah, nilai, keyakinan dan ideologi tertentu yaitu Islam. Karena jika ditelaah teori-teori proses pengambilan keputusan secara umum maka kita akan menemukan pendapatnya George Terry yang banyak dikutip oleh akademisi. George R. Terry sebagaimana dikutip Abduh (2016) mengemukakan beberapa dasar pengambilan keputusan, yaitu:

a. Intuisi; kebaikan dari hal ini adalah: (1) Waktu untuk mengambil keputusan relatif pendek, (2) Untuk masalah yang pengaruhnya terbatas, pengambilan keputusan akan memberikan keputusan pada umumnya, (3) Kemampuan mengambil keputusan dari pengambil keputusan itu sangat berperan dan perlu dimanfaatkan dengan baik. Sedangkan kelemahannya adalah: (1) Keputusan yang dihasilkan relatif kurang baik, (2) Sulit mencari alat pembandingnya sehingga sulit diukur kebenaran dan keabsahannya, dan (3) Dasar-dasar lain dalam pengambilan keputusan seringkali diabaikan.

b. Pengalaman; pengambilan keputusan melalui pengalaman memiliki manfaat bagi pengetahuan praktis. Karena pengalaman, seseorang dapat menduga masalahnya walaupun hanya dengan melihat sepintas saja sudah menemukan cara penyelesaiannya.

c. Fakta; dengan fakta, tingkat kepercayaan terhadap pengambil keputusan dapat lebih tinggi sehingga orang dapat menerima keputusan yang dibuat itu dengan rela dan lapang dada. Pengambilan keputusan berdasarkan fakta dapat memberikan keputusan yang sehat, solid, dan baik.

d. Wewenang; kelebihan dari wewenang ini adalah: (1) Kebanyakan penerimaannya adalah bawahan, terlepas apakah penerima tersebut menerima secara sukarela ataukah secara terpaksa, (2) Keputusannya dapat bertahan dalam jangka waktu yang cukup lama, (3) Memiliki otensitas. Sedangkan kelemahannya adalah: (1) Dapat menimbulkan sifat rutinitas, (2) Mengasosiasikan dengan praktik diktator, dan (3) Sering melewati permasalahan yang seharusnya dipecahkan dapat menimbulkan kekaburan.

e. Rasional; pada pengambilan keputusan dengan cara rasional, terdapat beberapa hal yaitu: (1) Kejelasan masalah, tidak ada keraguan dan kekaburan masalah, (2) Orientasi tujuan dan kesatuan pengertian tujuan yang ingin dicapai, (3) Pengetahuan alternatif, seluruh alternatif diketahui jenisnya dan konsekuensinya. Prefernsi yang jelas, alternatif bisa diurutkan sesuai kriteria, dan (3) Hasil maksimal yang mana pemilihan alternatif terbaik didasarkan atas hasil ekonomis yang maksimal.

Dasar pengambilan keputusan dalam Islam menurut Hadari Nawawi dalam Hasbi Abduh (2016), ada yang bersifat apostriori dan ada yang bersifat apriori. Proses Pengambilan keputusan yang bersifat apostriori menurut Hadari Nawawi mencakup: (1) al Qur'an, (2) Sunnah, (3) Ijma', (4) Qiyas. Sementara dasar pengambilan keputusan yang bersifat apriori berlangsung dijelaskan pada Gambar 1. 


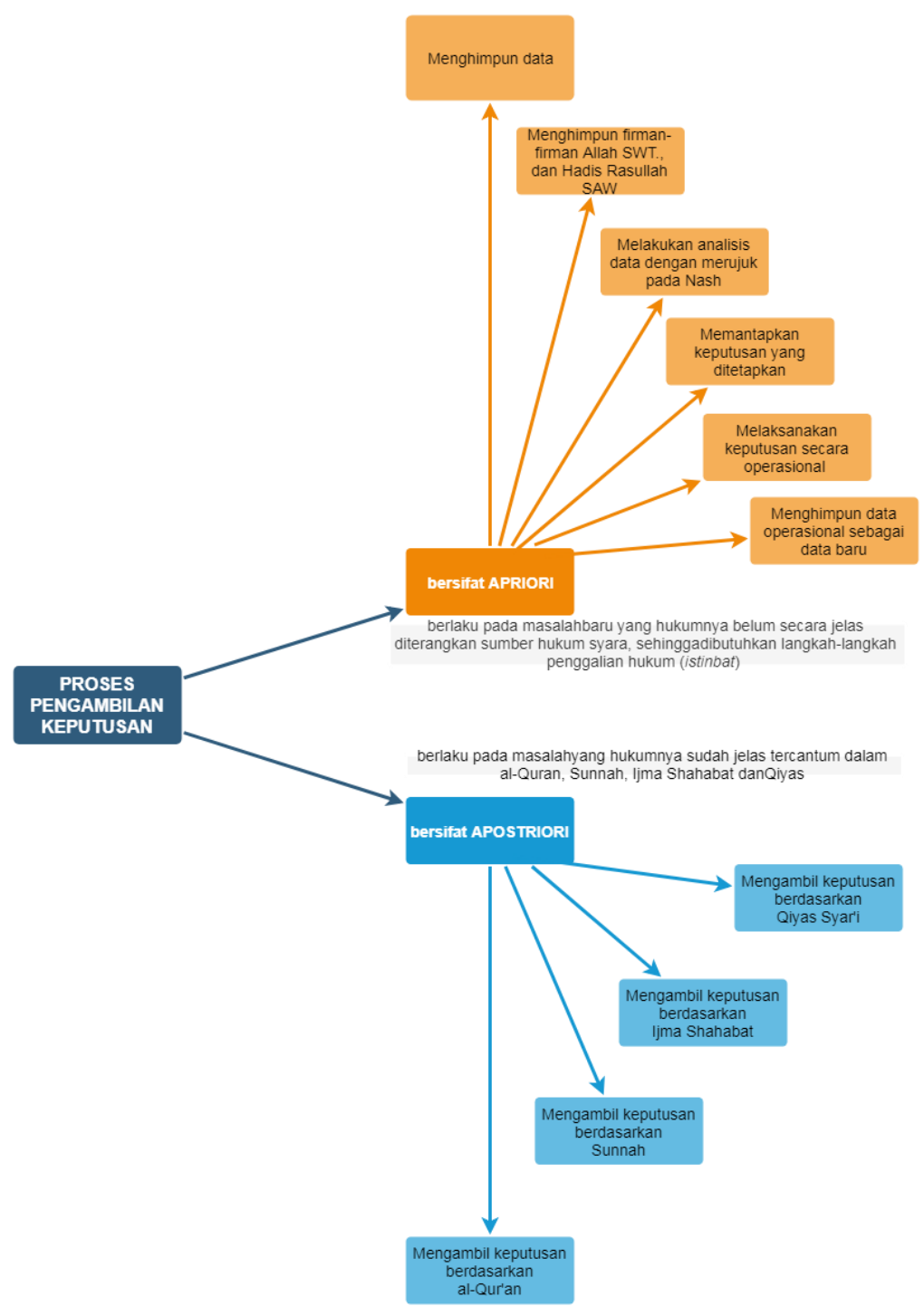

Gambar 1. Proses pengambilan keputusan islami

a. Menghimpun dan melakukan pencatatan serta pengembangan data, yang jika perlu dilakukan melalui kegiatan penelitian, sesuai dengan bidang yang akan ditetapkan keputusannya. Diantara ciri terpenting proses pengambilan keputusan adalah harus ditopang oleh kajian yang lama, tinjauan yang mendalam dan konsultasi yang tepat serta harus dikeluarkan tepat pada waktunya (Langgulung, 2000).

b. Menghimpun firman-firman Allah SWT., dan Hadis Rasullah SAW., sebagai acuan utama, sesuai dengan bidang yang akan di tetapkan keputusannya.

c. Melakukan analisis data dengan merujuk pada firman-firman Allah SWT., dan Hadis Rasulullah SAW., untuk memisahkan dan memilih yang relevan dan tidak relevan untuk dirangkai menjadi kebulatan.

d. Memantapkan keputusan yang ditetapkan, setelah meyakini tidak bertentangan dengan kehendak Allah SWT., berdasarkan firman-Nya dan Hadis Rasullah SAW.

e. Melaksanakan keputusan secara operasional dalam bentuk kegiatan kongkrit oleh para pelaksana.

f. Menghimpun data operasional sebagai data baru, baik yang mendukung ataupun yang menolak keputusan yang telah ditetapkan. Data tersebut dapat di pergunakan langsung untuk memperbaiki keputusan sebagai umpan balik (feedback), apabila ternyata terdapat kekeliruan.

Proses pengambilan keputusan yang bersifat apostriori adalah berlaku pada masalah yang hukumnya sudah jelas tercantum dalam al-Quran, Sunnah, Ijma Shahabat dan Qiyas. Sedangkan proses pengambilan keputusan yang bersifat apriori berlaku pada masalah baru yang hukumnya belum secara jelas diterangkan sumber hukum syara, sehingga dibutuhkan langkah-langkah penggalian hukum (istinbat) diatas. Langkah-langkah tersebut tidak jauh berbeda dengan teori-teori step by step pengambilan keputusan yang sudah ada yang meliputi perumusan masalah, pengumpulan dan analisis data, mengumpulkan alternatif keputusan, memilih keputusan dan evaluasi keputusan.

Perbedaan yang sangat prinsipil antara proses pengambilan keputusan dalam Islam dengan teori umum adalah keberadaan sandaran hukum Islam. Teori umum berpijak dari rasio atau bahkan suara mayoritas saja. Sedangkan proses pengambilan keputusan Islami berpijak pada rasio dan hukum Islam. Menurut Zallum (2013) suara mayoritas memainkan perannya hanya pada ranah masalah yang langsung berkaitan dengan amalan praktis yang tidak membutuhkan pemikiran dan pertimbangan mendalam. Sebab, mayoritas orang dipandang dapat memahamimya dan dapat memberikan pendapatnya dengan mudah sesuai dengan pertimbangan kemaslahatan yang ada. Hal ini berlandaskan hadist Nabi Saw:

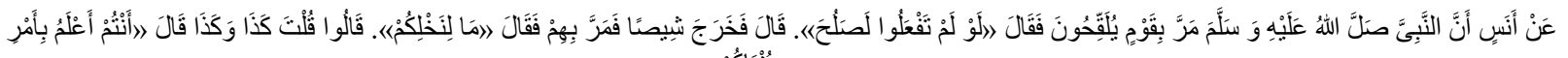

$$
\begin{aligned}
& \text { "إنْنَّاكُمْ }
\end{aligned}
$$


Dari Anas ra. dituturkan bahwa Nabi saw. pernah melewati satu kaum yang sedang melakukan penyerbukan kurma. Beliau lalu bersabda, "Andai kalian tidak melakukan penyerbukan niscaya kurma itu menjadi baik." Anas berkata: Pohon kurma itu ternyata menghasilkan kurma yang jelek. Lalu Nabi saw. suatu saat melewati lagi mereka dan bertanya, "Apa yang terjadi pada kurma kalian?" Mereka berkata, "Anda pernah berkata demikian dan demikian." Beliau pun bersabda, "Kalian lebih tahu tentang urusan dunia kalian.” (HR Muslim).

Imam an-Nawawi menjelaskan dalam Syarh Shahîh Muslim: Para ulama berkata, "Sabda Rasul saw. min ra'y[in] (berupa pendapat) artinya dalam perkara dunia dan ma'âyisy (mata pencaharian/penghidupan), bukan sebagai tasyri'. Adapun apa yang beliau sabdakan dengan ijtihad beliau dan yang beliau pandang sebagai syariah itu wajib diamalkan. Penyerbukan bukanlah termasuk dari jenis ini, tetapi termasuk jenis yang disebutkan sebelumnya."

Islam tidak datang mengatur amru dunya, yakni masalah teknis dan semacamnya itu secara detil. Islam hanya mengatur perkara itu melalui hukum-hukum umum. Detil teknis dan perkara eksperimental itu bisa dipilih sesuai hasil eksperimen, pengalaman, menurut situasi dan keadaan (seperti pola irigasi, rotasi tanaman, teknis produksi, cara manufaktur, dsb) selama dalam batas-batas koridor hukum-hukum syariah. Adapun dalam perkara-perkara agama, termasuk di dalamnya perkara tasyri', maka wajib hanya mengambil dan menerapkan apa yang dibawa oleh Rasul saw., yaitu syariah Islam saja (Yahya, 2014).

Sedangkan, masalah yang berhubungan dengan aspek-aspek profesi dan ide yang membutuhkan keahlian, pemikiran, dan pertimbangan yang mendalam yang dijadikan kriteria adalah ketepatan atau kebenarannya maka harus dikembalikan pada ahlinya (Zallum, 2013). Hal ini dapat dipahami dari hadist Rasulullah Muhammad SAW:

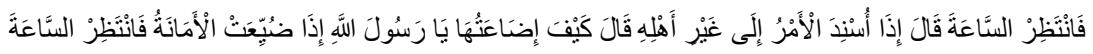

"Jika amanat telah disia-siakan, tunggu saja kehancuran terjadi." Ada seorang sahabat bertanya; "bagaimana maksud amanat disia-siakan? ' Nabi menjawab; "Jika urusan diserahkan bukan kepada ahlinya, maka tunggulah kehancuran itu." (Bukhari - 6015)

Dari empat sifat proses pengambilan keputusan Islami tersebut dapat diketahui model atau syarat yang harus dipenuhi pemimpin sebagai orang yang menjadi tumpuan pengambilan keputusan dijelaskan pada Gambar 2 .

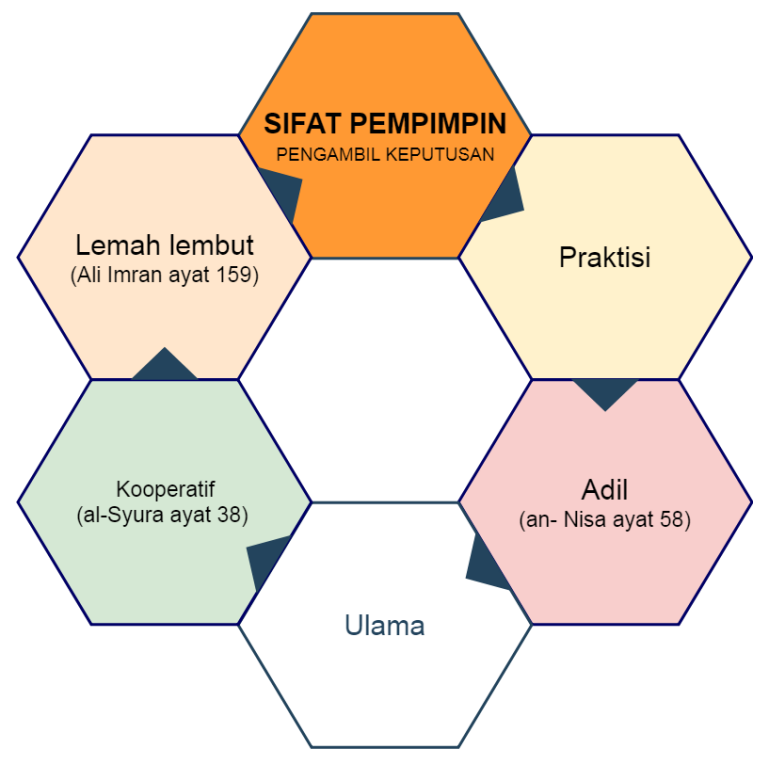

Gambar 2. Sifat pemimpin dalam pengambilan keputusan islami

a. Praktisi, karena pemimpin atau pengambil keputusan harus menghimpun dan melakukan pencatatan serta pengembangan data, yang jika perlu dilakukan melalui kegiatan penelitian, sesuai dengan bidang yang akan ditetapkan keputusannya. Kegiatan ini hanya bisa dilakukan oleh ahli yang bergerak dibidangnya.

b. Adil, dalam arti selalu menempatkan hukum Allah sebagai solusi. Memberi amanah pada ahlinya. Hal ini Allah perintahkan dalam al- Quran surat an- Nisa ayat 58:

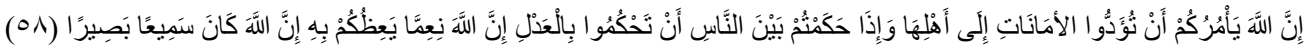

Sesungguhnya Allah menyuruh kamu menyampaikan amanat kepada yang berhak menerimanya, dan (menyuruh kamu) apabila menetapkan hukum di antara manusia supaya kamu menetapkan dengan adil. Sesungguhnya Allah memberi pengajaran yang sebaik-baiknya kepadamu. Sesungguhnya Allah adalah Maha mendengar lagi Maha melihat.

Adil dalam arti tidak tendensius pada pihak tertentu, pilih kasih, tidak inklusif. Karena Allah berfirman al- Quran surat al-Maidah ayat 8:

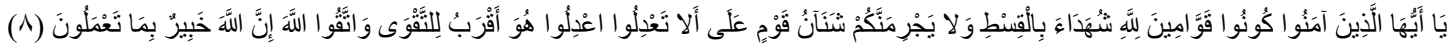

Hai orang-orang yang beriman hendaklah kamu jadi orang-orang yang selalu menegakkan (kebenaran) karena Allah, menjadi saksi dengan adil. dan janganlah sekali-kali kebencianmu terhadap sesuatu kaum, mendorong kamu untuk berlaku tidak adil. Berlaku adillah, karena adil itu lebih dekat kepada takwa. Dan bertakwalah kepada Allah, Sesungguhnya Allah Maha mengetahui apa yang kamu kerjakan.

Adil dalam arti mampu mengambil keputusan yang masuk akal, mampu direalisasikan, tidak berlebihan atau efisien, tidak overconfidence tapi confidence. Hal ini bisa ditelaah dalam al- Quran surat al-Baqarah ayat 286: 


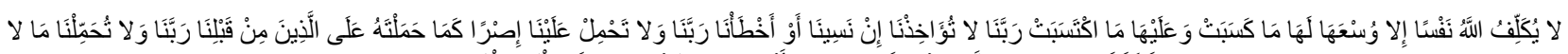

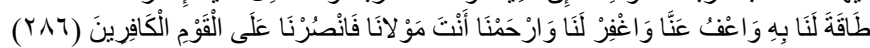

Allah tidak membebani seseorang melainkan sesuai dengan kesanggupannya. ia mendapat pahala (dari kebajikan) yang diusahakannya dan ia mendapat siksa (dari kejahatan) yang dikerjakannya. (mereka berdoa): "Ya Tuhan Kami, janganlah Engkau hukum Kami jika Kami lupa atau Kami tersalah. Ya Tuhan Kami, janganlah Engkau bebankan kepada Kami beban yang berat sebagaimana Engkau bebankan kepada orang-orang sebelum kami. Ya Tuhan Kami, janganlah Engkau pikulkan kepada Kami apa yang tak sanggup Kami memikulnya. beri ma'aflah kami; ampunilah kami; dan rahmatilah kami. Engkaulah penolong Kami, Maka tolonglah Kami terhadap kaum yang kafir."

c. Ulama, karena seorang pengambil keputusan harus menghimpun firman-firman Allah Ta'ala dan Hadis Rasulullah SAW., sebagai acuan utama, sesuai dengan bidang yang akan di tetapkan keputusannya dan melakukan analisis data dengan merujuk pada firman-firman Allah Ta'ala dan sunnah Rasulullah SAW., untuk memisahkan dan memilih yang relevan dan tidak relevan untuk di rangkai menjadi kebulatan.

d. Kooperatif dalam arti mau bekerjasama dan bermusyawarah. Mengambil pendapat dari pihak lain untuk dipertimbangkan sehingga mendapatkan keputusan yang lebih baik dan keputusan dilaksanakan secara bersama-sama dalam bentuk kegiatankegiatan kongkrit tanpa rasa terpaksa. Keputusan akan berjalan lancar apabila sejak semula dilibatkan dalam proses pengambilan keputusan. Itu berarti bahwa gaya musyawarah dalam proses pengambilan keputusan akan lebih menjamin keberhasilan pelaksanaan suatu program. Musyawarah ini Allah SWT tegaskan dalam al- Quran surat al-Syura ayat 38:

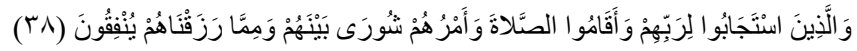

dan (bagi) orang-orang yang menerima (mematuhi) seruan Tuhannya dan mendirikan shalat, sedang urusan mereka (diputuskan) dengan musyawarat antara mereka; dan mereka menafkahkan sebagian dari rezki yang Kami berikan kepada mereka.

e. Lemah lembut, pengambil keputusan harus lemah lembut dalam bertutur dan bersikap, dalam mengambil informasi, dalam melarang dan mengajak termasuk dalam mengambil keputusan sehingga penerima keputusan menerima dengan suka hati. Allah SWT tegaskan hal ini dalam al- Quran surat Ali Imran ayat 159:

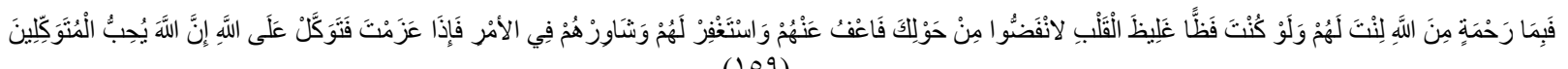

$$
\begin{aligned}
& \text { (109) }
\end{aligned}
$$

Maka disebabkan rahmat dari Allah-lah kamu Berlaku lemah lembut terhadap mereka. Sekiranya kamu bersikap keras lagi berhati kasar, tentulah mereka menjauhkan diri dari sekelilingmu. karena itu ma'afkanlah mereka, mohonkanlah ampun bagi mereka, dan bermusyawaratlah dengan mereka dalam urusan itu kemudian apabila kamu telah membulatkan tekad, Maka bertawakkallah kepada Allah. Sesungguhnya Allah menyukai orang-orang yang bertawakkal kepada-Nya.

Sehingga agar proses pengambilan keputusan berjalan dan berpengaruh efektif dan Islami maka ada prinsip atau pedoman yang harus dipenuhi yaitu sebagai berikut:

a. Proses pengambilan keputusan dipimpin oleh satu pemimpin yang memenuhi syarat diatas yaitu praktisi, adil, ulama, kooperatif dan lemah lembut.

b. Menjadikan Syariah Islam sebagai pedoman.

c. Jika masalah yang akan diambil keputusannya hukumnya sudah jelas diatur dalam hukum syara maka keputusan didasarkan pada hukum syara. Sedangkan jika masalah yang akan diambil keputusannya hukumnya belum jelas diatur dalam hukum syara maka harus melakukan penggalian hukum syara. Adapun jika masalah yang dihadapi adalah masalah yang mubah, alternatif solusinya bisa dipikirkan secara rasional maka bisa diambil suara mayoritas. Sedangkan jika masalahnya hanya bisa dipikirkan solusinya oleh ahli maka serahkan pada ahlinya.

d. Pengkajian fakta-fakta dari masalah diambil dari orang yang dapat dipercaya atau dikenal shalih, tidak diambil dari orang fasik atau orang yang sering melalaikan bahkan melanggar hukum syara. Allah SWT tegaskan hal ini dalam al- Quran surat alHujurat ayat 6:

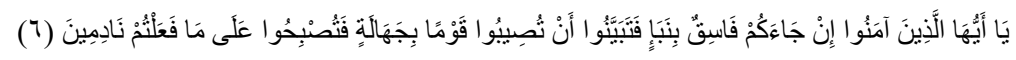

Hai orang-orang yang beriman, jika datang kepadamu orang Fasik membawa suatu berita, Maka periksalah dengan teliti agar kamu tidak menimpakan suatu musibah kepada suatu kaum tanpa mengetahui keadaannya yang menyebabkan kamu menyesal atas perbuatanmu itu.

e. Pengkajian fakta-fakta dari masalah serta keputusannya tidak diambil dengan cara prasangka umum, trend yang sedang berkembang atau opini atau keinginan umum di masyarakat tapi fakta dilihat secara objektif dan keputusan disandarkan pada hukum Allah SWT. Dalam al- Quran surat al-An'am ayat 116.

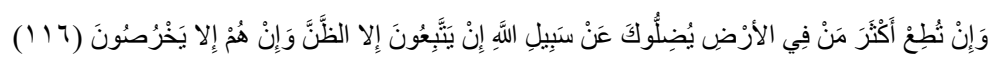

Dan jika kamu menuruti kebanyakan orang-orang yang di muka bumi ini, niscaya mereka akan menyesatkanmu dari jalan Allah. mereka tidak lain hanyalah mengikuti persangkaan belaka, dan mereka tidak lain hanyalah berdusta (terhadap Allah)

\subsection{Proses Pengambilan Keputusan Efektif Islami di MTs Al-Imam}

MTs Al-Imam berdiri dibawah yayasan Al-Imam yang berdiri tahun 1990-an merekrut anak-anak dari pulau terpencil. Kepala sekolah MTs Al-Imam yang sekarang menjabat adalah guru MTs Al-Imam yang telah bekerja dengan kesabaran dan keterbatasan dalam beberapa tahun. Sehingga pada tahun 2016 MTs Al-Imam diakreditasi dan mendapatkan hasil B.

Adapun visi MTs Al-Imam adalah terwujudnya generasi muslim berilmu, beriman, bertaqwa dan berakhlakul karimah. Sedangkan misinya adalah sebagai berikut:

a. Melahirkan generasi penghafal Al-Quran dan menguasai ilmu syar'i.

b. Mampu menguasai bahasa Arab dan Inggris secara aktif.

c. Mengembangkan lingkungan madrasah yang bersih, indah, nyaman dan kondusif. 
d. Melaksanakan pembelajaran dan bimbingan secara efektif sehingga siswa dapat berkembang secara optimal sesuai dengan potensi yang dimiliki.

e. Menyelenggarakan kegiatan keterampilan siswa agar dapat mengembangkan minat dan bakat yang dimiliki.

Adapun perbandingan mekanisme atau proses perumusan atau pengambilan keputusan terhadap hal-hal yang berkaitan dengan pengelolaan pendidikan di MTs Al-Imam dengan acuan Peraturan Menteri Pendidikan Nasional no. 19 tahun 2007 dijelaskan pada Tabel 1.

Tabel 1. Perbandingan Mekanisme Pengambilan Keputusan

\begin{tabular}{|c|c|c|c|}
\hline No & $\begin{array}{l}\text { Aspek } \\
\text { Pengelolaan }\end{array}$ & Standar Permendiknas no. 19 tahun 2007 & MTs. Al-Imam \\
\hline 1 & Visi & $\begin{array}{l}\text { Diputuskan oleh rapat Dewan Pendidik yang dipimpin oleh Kepala } \\
\text { Sekolah/madrasah dengan memperhatikan masukan Komite } \\
\text { Sekolah/madrasah; ditinjau dan dirumuskan kembali secara } \\
\text { berkala sesuai dengan perkembangan dan tantangan di }\end{array}$ & $\begin{array}{l}\text { Kepala sekolah bersama } \\
\text { rekan guru dengan cara } \\
\text { musyawarah bersama }\end{array}$ \\
\hline
\end{tabular}

$2 \quad$ Misi

3 Tujuan sekolah

4 Perumusan rencana kerja menengah dan tahunan

5 Memutuskan struktur organisasi sekolah

6 Pengelolaan bidang akademik

7 Penyusunan kurikulum

8 Penetapan kalender pendidikan/akad emik,

9 Kegiatan pembelajaran

10 Peraturan akademik

11 Pedoman pengelolaan biaya investasi dan operasional sekolah/madrasa h,

\section{Penciptaan} suasana, iklim, dan lingkungan pendidikan,

\section{masyarakat}

dirumuskan berdasarkan masukan dari segenap pihak yang berkepentingan termasuk Komite Sekolah/ madrasah dan diputuskan oleh rapat Dewan Pendidik yang dipimpin oleh Kepala Sekolah/madrasah; ditinjau dan dirumuskan kembali secara berkala sesuai dengan perkembangan dan tantangan di masyarakat.

Mengakomodasi masukan dari berbagai pihak yang berkepentingan termasuk Komite Sekolah/madrasah dan diputuskan oleh rapat Dewan Pendidik yang dipimpin oleh Kepala Sekolah/madrasah;

Rencana Kerja Jangka Menengah dan Tahunan sekolah/madrasah

:1) disetujui rapat Dewan Pendidik setelah memperhatikan pertimbangan dari Komite Sekolah/madrasah dan disahkan berlakunya oleh Dinas Pendidikan kabupaten/kota. Pada sekolah/madrasah swasta Rencana Kerja ini disahkan berlakunya oleh penyelenggara sekolah/madrasah

Dievaluasi secara berkala untuk melihat efektifitas mekanisme kerja pengelolaan sekolah; diputuskan oleh Kepala

Sekolah/madrasah dengan mempertimbangkan pendapat dari komite sekolah/madrasah

Kepala Sekolah/madrasah mempertanggung-jawabkan pelaksanaan pengelolaan bidang akademik pada rapat Dewan Pendidik dan bidang non-akademik pada Rapat Komite Sekolah/madrasah dalam bentuk Laporan pada Akhir Tahun Ajaran yang disampaikan sebelum penyusunan Rencana Kerja Tahunan berikutnya.

Kepala Sekolah/Madrasah bertanggungjawabatas tersusunnya KTSP. 5)Wakil Kepala SMP/MTs dan wakil kepala SMA/SMK/MA/MAK bidang kurikulum bertanggung-jawab atas pelaksanaan penyusunan KTSP.

Penyusunan kalender pendidikan/akademik: diputuskan dalam Rapat Dewan Pendidik dan ditetapkan oleh Kepala Sekolah/madrasah.

Kepala Sekolah/madrasah bertanggungjawab terhadap kegiatan pembelajaran sesuai dengan peraturan yang ditetapkan Pemerintah.

Peraturan Akademik diputuskan oleh Rapat Dewan Pendidik dan ditetapkan oleh Kepala Sekolah/madrasah.

Pedoman pengelolaan biaya investasi dan operasional sekolah/madrasah diputuskan oleh Komite Sekolah/madrasah dan ditetapkan oleh Kepala Sekolah/madrasah serta mendapatkan persetujuan dari institusi di atasnya.

Prosedur pelaksanaan penciptaan suasana, iklim,dan lingkungan pendidikan: diputuskan oleh Kepala Sekolah/ madrasah dalam Rapat Dewan Pendidik.
Kepala sekolah bersama rekan guru dengan cara musyawarah bersama.

Kepala sekolah bersama rekan guru dengan cara musyawarah bersama

Perumusannya dengan diadakannya raker kepala sekolah bersama staff pangajar

Kepala sekolah/madrasah bersama bagian kesiswaan dan staff lainnya.

Kepala sekolah bertanggungjawab atas semua yang menyangkut urusan sekolah

Melalui staff kurikulum yang disesuaikan dengan kementrian agama

Melalui staff kurikulum yang disesuaikan dengan kementrian agama

Dalam bentuk pengontrolan terhadap proses KBM pada waktu-waktu tertentu Menetapkan aturan yang disesuaikan dengan kementrian agama Dalam menetapkan pengelolaan dana disesuaikan dengan kebutuhan sekolah dalam bentuk laporan yang berbentuk rencana kebutuhan anggaran madrasah serta LPJ Dimulai dengan cara pembinaan terhadap guru. 


\begin{tabular}{|c|c|c|c|}
\hline No & $\begin{array}{l}\text { Aspek } \\
\text { Pengelolaan }\end{array}$ & Standar Permendiknas no. 19 tahun 2007 & MTs. Al-Imam \\
\hline 13 & $\begin{array}{l}\text { Tata tertib } \\
\text { sekolah/madrasa } \\
\mathrm{h}\end{array}$ & $\begin{array}{l}\text { Tata Tertib Sekolah/madrasah ditetapkan oleh Kepala } \\
\text { Sekolah/madrasah melalui Rapat Dewan Pendidik dengan } \\
\text { mempertimbangkan masukan Komite Sekolah/madrasah, dan } \\
\text { peserta didik. }\end{array}$ & $\begin{array}{l}\text { Berdasarkan musyawarah } \\
\text { dan dimulai penerapannya } \\
\text { dengan pembiasaan } \\
\text { terhadap guru dan peserta } \\
\text { didik dalam hal kedisiplinan. }\end{array}$ \\
\hline 14 & $\begin{array}{l}\text { Kode etik } \\
\text { sekolah/madrasa } \\
\text { h, }\end{array}$ & $\begin{array}{l}\text { Kode Etik Sekolah/madrasah diputuskan oleh Rapat Dewan } \\
\text { Pendidik dan ditetapkan oleh Kepala Sekolah/madrasah. }\end{array}$ & $\begin{array}{l}\text { Disesuaikan dengan } \\
\text { peraturan Kemenag yang ada }\end{array}$ \\
\hline 15 & $\begin{array}{l}\text { Evaluasi proses } \\
\text { pembelajaran }\end{array}$ & $\begin{array}{l}\text { Evaluasi Proses Pembelajaran secara periodik, sekurang- } \\
\text { kurangnya dua kali dalam setahun, pada akhir semester akademik; }\end{array}$ & $\begin{array}{l}\text { Dengan menyelenggarakan } \\
\text { UTS, UAS dan UKK }\end{array}$ \\
\hline 16 & $\begin{array}{l}\text { Evaluasi program } \\
\text { kerja tahunan. }\end{array}$ & $\begin{array}{l}\text { Evaluasi Program Kerja Tahunan secara periodik sekurang- } \\
\text { kurangnya satu kali dalam se-tahun, pada akhir tahun anggaran } \\
\text { sekolah/madrasah. }\end{array}$ & $\begin{array}{l}\text { Melalui jurnal bulanan } \\
\text { kepala sekolah dan dalam hal } \\
\text { anggaran ada LPJ }\end{array}$ \\
\hline
\end{tabular}

Analisis proses pengambilan keputusan di MTs Al-Imam berdasarkan hasil wawancara dan kuisioner dikaitkan dengan standar Permendiknas no. 19 tahun 2007 adalah sebagai berikut:

a. Bahwa secara umum MTs Al-Imam sudah sesuai dengan standar yang ditetapkan Permendiknas no. 19 tahun 2007 dalam hal pengelolaan pendidikan terutama berkaitan dengan tugas kepala sekolaah/madrasah dalam memutuskan atau menetapkan sebuah kebijakan pengelolaan. Kesesuaian itu karena masih sederhananya struktur organisasi MTs Al-Imam.

b. Keputusan kepala madrasah melalui rapat dewan pendidik tidak selalu final karena diatas MTs Al-Imam ada yayasan Al-Imam yang menaungi MTs Al-Imam. Misalnya, dalam rapat dewan akademik disepakati penghapusan salah satu misi MTs Al-Imam yaitu mampu menguasai bahasa Inggris secara aktif. Karena para dewan pendidik sadar bahwa input, sumber daya pendidik dan sarana serta prasarana untuk mencapai misi ini tidak mendukung. Namun, ditolak oleh pimpinan yayasan Al-Imam maka misi itupun tetap disematkan dalam misi MTs Al-Imam. Peneliti melihat ada pengaruh kepala yayasan dengan riwayat pendidikannya di Pesantren Modern Gontor yang ingin menerapkan misi yang sama di MTs Al-Imam di satu sisi. Dari kuisioner tentang kompetensi kepemimpinan yayasan maka dapat didapatkan kompetensi kepribadian berupa sikap terbuka mendapat nilai K (kurang), point 2.3. point kompetensi manajerial yaitu memimpin sekolah/ madrasah dalam rangka pendayagunaan sumber daya sekolah/madrasah secara optimal mendapat nilai K (kurang) serta point 2.16. point kompetensi manajerial yaitu melakukan monitoring, evaluasi, dan pelaporan pelaksanaan program kegiatan sekolah/madrasah dengan prosedur yang tepat serta merencanakan tindak lanjutnya mendapat nilai K (kurang).

c. Pihak yayasan mengambil posisi dominan terhadap berbagai kebijakan pokok akademik madrasah. Misalnya pada penentuan kurikulum. Dewan pendidik menyesuaikan dengan peraturan Kementrian agama yang tetap menyediakan jam untuk pelajaran umum sedangkan yayasan ingin pelajaran umum dihapus. Ini menjadi konflik internal yang membuat dilema kepala madrasah sebagai pengambil keputusan.

Jika kita mengacu pada prinsip proses pengambilan keputusan efektif Islami maka ada beberapa hal yang harus diperhatikan pihak yayasan Al-Imam dan MTs Al-Imam yaitu sebagai berikut:

a. Harus ada pembagian kewenangan yang jelas antara pimpinan yayasan dan kepala madrasah melalui evaluasi struktur organisasi. Sehingga jelas pihak yang berwenang mengambil keputusan dalam setiap bidang garapannya. Tidak saling menjegal keputusan.

b. Dalam pengelolaan akademik sekolah/madrasah percayakan pada ahli/praktisi. Karena selain pengelolaan akademik sekolah/madrasah masih banyak bidang garapan lainnya.

c. Jadikan hukum Islam sebagai pedoman pengambilan keputusan agar tidak terjadi kejanggalan kebijakan. Misalnya, disatu sisi pihak yayasan menginginkan penghapusan pelajaran/ilmu umum (fardlu kifayah), di sisi lain memaksakan pelajaran atau pembiasaan bahasa Inggris (mubah). Buatlah skala prioritas berdasarkan hukum Islam ilmu yang harus dipelajari peserta didik. Tidak harus terpaku pada kurikulum Kementrian Agama saja atau kurikulum suatu lembaga pendidikan tertentu.

d. Rancangan kurikulum secara teori disesuaikan dengan sumber daya yang dimiliki sekolah. Jika mengadopsi kurikulum dari lembaga pendidikan lain maka tentu harus ada beberapa penyesuaian. Misalnya, standar kompetensi dan kompetensi dasarnya diturunkan atau dinaikkan agar kurikulum bisa dijalankan. Untuk bisa memahami ini dibutuhkan penggalian informasi yang terpercaya, data yang akurat dan praktisi yang berpengalaman dan menguasai lingkungan. Sehingga kurikulum yang dirancang tidak overconfidence. Pengambil keputusan harus memahami ini agar keputusan tentang kurikulum efektif dan adil.

Ketika pemimpin yayasan ingin intervensi dalam pengelolaan pendidikan MTs Al-Imam gunakan jalur koordinasi bukan intruksi. Maka kumpulkan dewan/praktisi akademik, samakan persepsi terhadap suatu pembahasan, berikan argumentasi yang kuat atas keputusan yang berkaitan dengan program akademik, berikan kesempatan forum untuk berbicara dan sepakati. Hal ini akan menimbulkan rasa puas dan rasa memiliki para dewan akademik MTs Al Imam terhadap keputusan pimpinan yayasan walau bersifat intervensi.

\section{KESIMPULAN}

Setiap organisasi khususnya sekolah membutuhkan adanya pemimpin yang mampu mengelola dan mengambil keputusan. Keputusan yang diambil idealnya efektif dalam arti menyelesaikan masalah dan berdampak positif serta Islami dalam arti keputusannya didasarkan pada nilai, keyakinan, hukum atau ideologi Islam. Adapun proses pengambilan keputusan efektif Islami di sekolah adalah sebagai berikut:

a. Proses pengambilan keputusan dipimpin oleh satu pemimpin yang memenuhi syarat di atas yaitu praktisi, adil, ulama, kooperatif dan lemah lembut.

b. Menjadikan Syariah Islam sebagai pedoman. 
c. Jika masalah yang akan diambil keputusannya hukumnya sudah jelas diatur dalam hukum syara maka keputusan didasarkan pada hukum syara. Sedangkan jika masalah yang akan diambil keputusannya hukumnya belum jelas diatur dalam hukum syara maka harus melakukan penggalian hukum syara. Adapun jika masalah yang dihadapi adalah masalah yang mubah, alternatif solusinya bisa dipikirkan secara rasional maka bisa diambil suara mayoritas. Sedangkan jika masalahnya hanya bisa dipikirkan solusinya oleh ahli maka serahkan pada ahlinya.

d. Pengkajian fakta-fakta dari masalah diambil dari orang yang dapat dipercaya atau dikenal shalih, tidak diambil dari orang fasik atau orang yang sering melalaikan bahkan melanggar hukum syara.

e. Pengkajian fakta-fakta dari masalah serta keputusannya tidak diambil dengan cara prasangka umum, trend yang sedang berkembang atau opini atau keinginan umum di masyarakat tapi fakta dilihat secara objektif dan keputusan disandarkan pada hukum Allah SWT.

f. Kemudian, beberapa hal yang harus diperhatikan pihak yayasan Al-Imam dan MTs Al-Imam dalam proses pengambilan keputusan efektif islami yaitu :

i. Harus ada pembagian kewenangan yang jelas antara pimpinan yayasan dan kepala madrasah sehingga jelas siapa yang berwenang mengambil keputusan.

ii. Diperlukan kapabilitas dalam pengelolaan akademik sekolah/ madrasah.

iii. Menjadikan hukum Islam sebagai pedoman pengambilan keputusan.

iv. Diperlukan SOP dan Tupoksi dalam pengelolaan akademik sekolah/ madrasah.

\section{Daftar Pustaka}

Abduh, H. (2016). Pengambilan Keputusan di Lembaga Pendidikan. Hikmah: Jurnal Pendidikan Islam, 4(1), 26-50.

Bin Tata Rosita, T., Syahidin, S., \& Rizal, A. (2019). Prinsip Dasar Falsafah Akhlak Omar Mohammad Al-Toumy Al-Syaibany dan Implikasinya dalam Pendidikan di Indonesia. Jurnal Kajian Peradaban Islam, 2(1), 10-17.

Indonesia, R. (1945). Undang-Undang Dasar Negara Republik Indonesia 1945. Diambil dari http://www. dpr. go. id/uu/uu1945.

Indonesia, R. (2003). Undang-undang Republik Indonesia nomor 20 tahun 2003 tentang sistem pendidikan nasional. Jakarta: Pemerintah Republik Indonesia.

Indonesia, R. (2007). Peraturan Menteri Pendidikan Nasional no. 19 tahun 2007. Jakarta: Pemerintah Republik Indonesia.

Indonesia, R. (2007). Peraturan Menteri Pendidikan Nasional no. 13 tahun 2007. Jakarta: Pemerintah Republik Indonesia.

Kodrat, D. D. (2019). Urgensi Perubahan Pola Pikir Dalam Membangun Pendidikan Bermutu. Jurnal Kajian Peradaban Islam, 2(1), 1-6.

Langgulung, H. (2000) Asas-asas Pendidikan Islam. Jakarta: Alhusna Zikra.

Putra, V. M. (2014). Persepsi Guru Terhadap Pengambilan Keputusan Kepala Sekolah di SMK Negeri Kelompok Bisnis Manajemen Kota Padang. Bahana Manajemen Pendidikan, 2(1), 755-763.

Rahmat, A. (2013), Manajemen Pendidikan Islam. Gorontalo: Ideas Publishing.

Salusu, J. (1996). Pengambilan Keputusan Stratejik untuk Organisasi Publik dan Organisasi Non-Profit. Ujung Pandang: Grasindo.

Yahya, A. (2014). Makna “Antum A'lamu Bi Amri Dunyakum”. Diambil dari http://www.dakwahjateng.net/2014/12/maknaantum-alamu-bi-amri-dunyakum.html

Zallum, A. Q. (2003). Demokrasi Sistem Kufur: Haram Mengambil, Menerapkan, dan Menyebarluaskannya. Bogor, Pustaka Thariqul Izzah. 